\title{
Coprecipitation of Cadmium with Calcium Carbonate from Aqueous Solutions at 15 to $50^{\circ} \mathrm{C}$
}

\author{
Tetsu KumagaI and Masakazu Matsui* \\ Department of Engineering Science, Faculty of Engineering, Himeji Institute of Technology \\ 2167, Shosha, Himeji-shi, Hyogo-Pref. 671-22, Japan \\ *Institute for Chemical Research, Kyoto University \\ Uji-shi, Kyoto-Pref. 611, Japan \\ Received September 24, 1991
}

\begin{abstract}
The distribution behavior of cadmium between precipitates of calcite and aragonite, and saturated aqueous solutions were studied at $15,25,40$ and $50^{\circ} \mathrm{C}$. Calcium carbonate crystal was precipitated from calcium hydrogencarbonate solutions by homogeneous precipitation method. Aragonite crystal was precipitated from the solution containing magnesium perchlorate. The logarithmic distribution law ruled these systems, and the distribution coefficient, $\lambda$, was calculated from the concentration of cadmium and calcium in the solution. By using the ratio of solubility product constants $K_{\text {calcite }} / K_{\mathrm{CdCO}_{3}}=731, K_{\mathrm{aragonite}} / K_{\mathrm{CdCO}_{3}}=1010$, and distribution coefficients $\lambda_{\mathrm{ca} 1}=350, \lambda_{\mathrm{arg}}=6.23$, excess free energy values were calculated as $\Delta \mu_{\mathrm{cal}}=1.76 \mathrm{~kJ}$ $\mathrm{mol}^{-1}, \Delta \mu_{\mathrm{arg}}=12.5 \mathrm{~kJ} \mathrm{~mol}^{-1}$ at $25^{\circ} \mathrm{C}$. The difference of these values is dependent on the fact that calcite and cadmium carbonate crystals belong to hexagonal system, but aragonite crystal belongs to rhombic one.
\end{abstract}

Key Words : coprecipitation, aragonite, calcite, cadmium, cadmium- $115 \mathrm{~m}$ tracer

According to sedimentation or dissolution of minerals in the marine or inlandwater systems, trace elements are being transported between precipitates and water. Estimation of distribution ratio of trace elements with macro elements is an important part of geochemistry from the interest of circulation of matters, and leads us to the information of thermodynamic conditions for mineral formation. Calcium carbonate is a popular sediment which is shown in various places, and incorporation of trace elements with calcite or aragonite is one of interesting phenomena. Many studies about coprecipitation of trace elements with calcium carbonate have been studied $^{1)-11)}$. As trace elements are incorporated with precipitates in several manners, solid solution formation is the most essential source of coprecipitation in this case, which can be treated by thermodynamical procedure. The present work is a study of the distribu- tion behavior of cadmium with calcite and aragonite which precipitated from calcium hydrogencarbonate solution at 15 to $50^{\circ} \mathrm{C}$.

\section{Experimental}

1.1 Apparatus and reagents

The radioactivity counting of cadmium$115 \mathrm{~m}\left({ }^{115 \mathrm{~m}} \mathrm{Cd}, \beta_{\max }, 1.62 \mathrm{MeV}\right)$ was made by a Packard Tricarb Liquid Scintillation Spectrometer, Model 3320. A stock solution of radioisotope, ${ }^{115 \mathrm{~m}} \mathrm{Cd}$ which was supplied by New England Nuclear, Mass., U.S.A., as chloride in hydrochloric acid was diluted to about $37-74 \mathrm{kBq} \mathrm{cm}^{-3}$ radioactivity and $0.05 \mathrm{~mol}$ $\mathrm{dm}^{-3}$ acidity by hydrochloric acid. A calcium hydrogencarbonate solution was freshly prepared by bubbling carbon dioxide into a calcium carbonate suspension, (about $1 \mathrm{~g} \mathrm{CaCO}_{3}$ in $1 \mathrm{dm}^{3}$ distilled water), for several hours, and filtering it to remove residue by a filter paper. Carbon dioxide was then passed again 
through the filtrate for half an hour. The concentration of calcium hydrogencarbonate solution was about $0.01 \mathrm{~mol} \mathrm{dm}^{-3}$. A stock solution of $5 \mathrm{mmol} \mathrm{dm} \mathrm{dm}^{-3}$ cadmium was prepared from reagent-grade nitrate.

A magnesium perchlorate solution was prepared to make aragonite precipitate from the calcium hydrogencarbonate solution. 2, $2^{\prime}$ Bipyridyl was used as a ligand with cadmium to reduce the activity of cadmium. A thermostated water bath (within $\pm 0.1^{\circ} \mathrm{C}$ ) was used throughout the experiment. Standard EDTA titration method was used for determination of calcium and magnesium. Concentration of calcium and magnesium was determined using Eriochrome Black T, (EBT), indicator and ammonia-ammonium chloride buffer, and concentration of calcium was determined using 3-hydroxy-4-(2-hydroxy-4-sulfo-1-naphthylazo)2-naphthoic acid, (NN), indicator and $8 \mathrm{~mol}$ $\mathrm{dm}^{-3}$ potassium hydroxide solution. A $1 \mathrm{dm}^{3}$ of liquid scintillator for $\beta^{-}$counting was prepared by dissolving $100 \mathrm{mg}$ of 1 , 4-bis (5phenyl-2-oxazolyl)benzene, (POPOP), $4 \mathrm{~g}$ of 2,5-diphenyloxazole, (DPO), and $75 \mathrm{~g}$ of naphthalene with dioxane.

All the other reagents were reagent-grade materials.

\subsection{Procedure}

One liter of the aqueous solution containing calcium hydrogencarbonate, cadmium ( $5 \mu \mathrm{mol}$ $\left.\mathrm{dm}^{-3}\right),{ }^{115 \mathrm{~m}} \mathrm{Cd}$ as a tracer and magnesium perchlorate in the case of aragonite formation were taken in an Erlenmeyer flask. The solution in the flask which was supported in the water-bath was stirred by teflon-coated magnet bar at $15,25,40$ and $50^{\circ} \mathrm{C}$. Calcium carbonate crystals were precipitated from the calcium hydrogencarbonate solution by gradual release of carbon dioxide gas through the narrow glass tube fitted with the flask. Since aragonite crystal is precipitated from the solution containing magnesium ion, $0.025 \mathrm{~mol} \mathrm{dm}^{-3}$ of magnesium perchlorate was used to make aragonite crystal in this experiment. A crystal form of precipitate was determined by X-ray diffraction method using by a Shimadzu X-ray Diff raction Model AZ-2A. Precipitation speed was controlled by varying the diameter and length of glass tube.

The concentrations of calcium and cadmium in the solution were measured by the following method. Seven $\mathrm{ml}$ each of a supernatant solution was pipetted out at suitable interval of time, and precipitate was removed by centrifugal method. Cadmium activities in the solution phase were counted with a liquid scintillation spectrometer after $2 \mathrm{~cm}^{3}$ of the $0.1 \mathrm{~mol} \mathrm{dm}^{-3}$ of hydrochloric acid and $15 \mathrm{~cm}^{3}$ of liquid scintillator had been added to $2 \mathrm{~cm}^{3}$ of the sample solution. As initial concentration of cadmium was fixed $5 \mu \mathrm{mol} \mathrm{dm}^{-3}$ in this experiment, concentration of cadmium was calculated from the observed radioactivity.

The concentrations of calcium and magnesium were determined by titration using a $0.002 \mathrm{~mol} \mathrm{dm}^{-3}$ EDTA solution.

\section{Results}

Aragonite was precipitated from the calcium hydrogencarbonate solution containing 0.025 mol $\mathrm{dm}^{-3}$ of magnesium perchlorate and calcite was not detected by X-ray reflections (for example, aragonite $26.6^{\circ} 2 \theta /$ calcite $29.4^{\circ} 2 \theta$, $\mathrm{CuK}_{\alpha}$ ). Magnesium ions in the aragonite precipitates could not be detected by atomic absorption spectrometry.

When a crystal grows from a saturated solution, coexisting micro components of ten coprecipitate in several processes, surface adsorption, occlusion and solid solution formation. Surface adsorption and occlusion are caused by active surface energy in fine size crystal.

Solid solution formation, the most common case, can be treated by thermodynamically, for the trace element substitutes for a normal atom at a regular lattice position. Distribution coefficient of the homogeneous distribution 
law, $D$ is expressed as follows:

$$
D=\frac{C_{\mathrm{Ca}} \cdot M_{\mathrm{CdCO}_{3}}}{C_{\mathrm{Cd}} \cdot M_{\mathrm{CaCO}_{3}}}
$$

Here $C_{\mathrm{Ca}}$ and $C_{\mathrm{Cd}}$ are the total concentration of calcium and cadmium ions in the solution. $M_{\mathrm{CaCO}}$ and $M_{\mathrm{CdCO}_{3}}$ are the mole fraction of calcium and cadmium in the carbonate crystal.

Distribution coefficient of logarithmic distribution law, $\lambda$, which holds good when the equilibrium between liquid phase and surface of solid phase is achieved, is expressed as follows:

$$
\lambda=\log \frac{C_{\mathrm{Cd}, \text { initia: }}}{C_{\mathrm{Cd}, \mathrm{final}}} / \log \frac{C_{\mathrm{Ca}, \text { initial }}}{C_{\mathrm{Ca}, \mathrm{final}}}
$$

2,2'-Bipyridyl, which scarcely reacts with calcium ions, was used to decrease the cadmium activity. Concentration of the ligand was varied from $0.2 \mathrm{mmol} \mathrm{dm}^{-3}$ to $3.7 \mathrm{mmol} \mathrm{dm}^{-3}$.

Concentration variation of $2,2^{\prime}$-bipyridyl with precipitation of calcium carbonate, which was measured by photometric method using standard iron(II) ion, was not detected within experimental errors. The relationship of the total concentration and the molar concentration of cadmium are represented in the following equations:

$$
\begin{aligned}
& C_{\mathrm{Cd}}=m_{\mathrm{Cd}} \cdot\left(1+\Sigma \beta_{i}{ }^{\mathrm{CdL}} \cdot m_{\mathrm{L}}{ }^{i}\right) \\
& \mathrm{C}_{\mathrm{L}}=m_{\mathrm{L}} \cdot\left(1+\Sigma \beta_{i}{ }^{\mathrm{LH}} \cdot[\mathrm{H}]^{i}\right)+m_{\mathrm{Cd}} \cdot \Sigma \beta_{i}{ }^{\mathrm{Cd} \mathrm{L}} \cdot m_{\mathrm{L}}{ }^{i}
\end{aligned}
$$

Here $C_{\mathrm{Cd}}, C_{\mathrm{L}}$ are the total concentration of cadmium and 2,2'-bipyridyl, $m_{\mathrm{Cd}}$ and $m_{\mathrm{L}}$ are the molar concentration of cadmium and 2,2'bipyridyl, $\beta_{i}{ }^{\mathrm{CdL}}$ and $\beta_{i}{ }^{\mathrm{LH}}$ denote the stepwise or overall stability constants of cadmium and proton complexes with ligand. $m_{\mathrm{Cd}}$ can be neglected because $m_{\mathrm{Cd}} \ll m_{\mathrm{L}}, \log \beta_{1}=4.47, \mathrm{pH} \simeq$ 8, so Eq. (4) is modified as follows:

$$
m_{\mathrm{L}}=C_{\mathrm{L}} /\left(1+\Sigma \beta_{i}{ }^{\mathrm{LH}} \cdot[\mathrm{H}]^{i}\right) \simeq C_{\mathrm{L}}
$$

True distribution coefficient $\lambda$ was calculated from following equation using the apparent distribution coefficient, $\lambda^{\prime}$.

$$
\lambda=\left(1+\Sigma \beta_{i}{ }^{\mathrm{cdL}} \cdot m_{\mathrm{L}}{ }^{i}\right) \cdot \lambda^{\prime}
$$

Stability constants of cadmium-2,2'-bipyridyl complex $^{12)}$ which were calculated from $\Delta H$ and $\Delta S$ data, were 4.06 for $\log K_{1}, 3.45$ for $\log K_{2}$ and 2.55 for $\log K_{3}$ at $25^{\circ} \mathrm{C}$. Figures 1 and 2 show the representative coprecipitation behavior of cadmium with calcite and aragonite at various temperatures and various

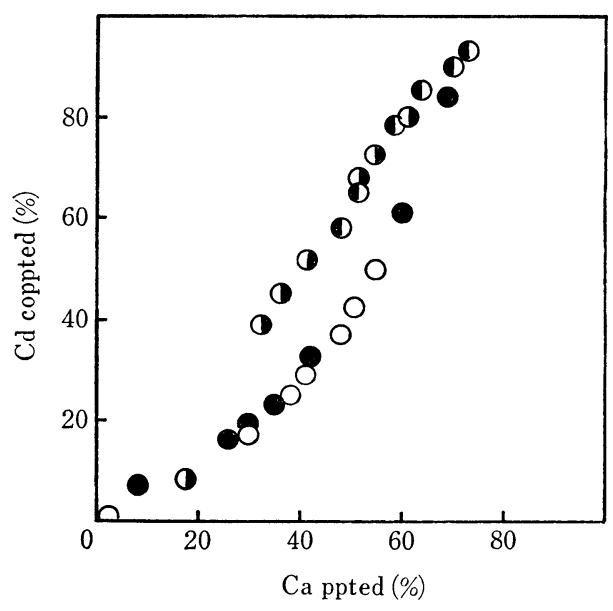

Fig. 1 Coprecipitation of cadmium with calcite from $15^{\circ} \mathrm{C}$ to $50^{\circ} \mathrm{C}$.

: $15^{\circ} \mathrm{C} ;[\mathrm{L}]=1.7 \mathrm{mmol} \mathrm{dm} \mathrm{dm}^{-3}$

(1): $25^{\circ} \mathrm{C} ;[\mathrm{L}]=2.0 \mathrm{mmol} \mathrm{dm} \mathrm{m}^{-3}$

D: $40^{\circ} \mathrm{C} ;[\mathrm{L}]=2.5 \mathrm{mmol} \mathrm{dm} \mathrm{dm}^{-3}$

: $50{ }^{\circ} \mathrm{C} ;[\mathrm{L}]=3.1 \mathrm{mmol} \mathrm{dm} \mathrm{dm}^{-3}$

L ; $2,2^{\prime}$-Bipyridyl.

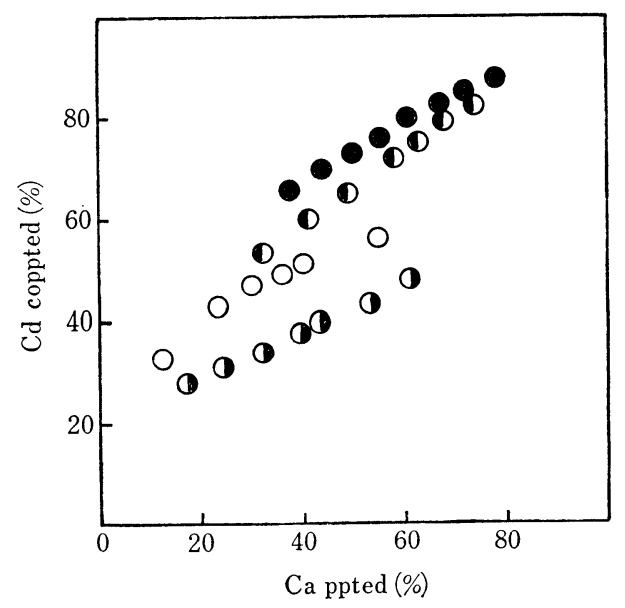

Fig. 2 Coprecipitation of cadmium with aragonite from $15^{\circ} \mathrm{C}$ to $50^{\circ} \mathrm{C}$.

O: $15^{\circ} \mathrm{C}:[\mathrm{L}]=0.30 \mathrm{mmol} \mathrm{dm}{ }^{-3}$

(1): $25^{\circ} \mathrm{C} ;[\mathrm{L}]=0.30 \mathrm{mmol} \mathrm{dm}{ }^{-3}$

D: $40^{\circ} \mathrm{C} ;[\mathrm{L}]=0.32 \mathrm{mmol} \mathrm{\textrm {dm } ^ { - 3 }}$

: $50{ }^{\circ} \mathrm{C} ;[\mathrm{L}]=0.35 \mathrm{mmol} \mathrm{dm}{ }^{-3}$

L ; $2,2^{\prime}$-Bipyridyl. 
ligand concentrations. Surface of crystal in the stage of nuclear generation is very active to adsorb cadmium and to make occlusion, and coprecipitation is influenced by the degree of supersaturation, so the curves were not extrapolated to the zero point.

Calculation of distribution coefficient must be made by removing the data of early stage of precipitation.

\section{Discussion}

\subsection{Effect of supersaturation}

It is known that distribution of the trace element with the carrier element becomes nonequilibrium when the crystal grows from a supersaturated solution, and the apparent distribution coefficient, $\lambda^{\prime}$ becomes a function of the degree of supersaturation, $S$. The relation had been reported by Riehl et al. ${ }^{13)}$.

When the diffusion constants of carrier and trace elements are the same, the equation is as follows:

$$
\lambda^{\prime}=\lambda S \cdot\{\lambda(S-1)+1\}^{-1}
$$

When the distribution coefficient of a system is far larger than 1, apparent coefficient, $\lambda^{\prime}$ is observed smaller than true coefficient, $\lambda$ from Eq. (7). 2,2'-Bipyridyl was added into the solution to reduce the influence of supersaturation and to make the apparent distribution coefficient nearly equal to unity. The effect of $2,2^{\prime}$ bipyridyl on the distribution coefficient calculation from Eq. (6) is shown in Fig. 3.

Concentration effect of ligand did not exist within this range. Comparing the growing rate of calcite with that of aragonite, the former is larger than the latter under the same condition, especially the first stage of precipitation. Effect of supersaturation was investigated varying the release rate of carbon dioxide gas, and calculations were made to diminish the effect of adsorption, occlusion and supersaturation as follows:

$$
\lambda_{i, j}=\log \left(\frac{C_{\mathrm{Cd}, i}}{C_{\mathrm{Cd}, j}}\right) / \log \left(\frac{C_{\mathrm{Ca}, i}}{C_{\mathrm{Ca}, j}}\right)(i<j)
$$

$C_{\mathrm{Ca}, i}$ and $C_{\mathrm{Cd}, i}$ are the concentration of cal-

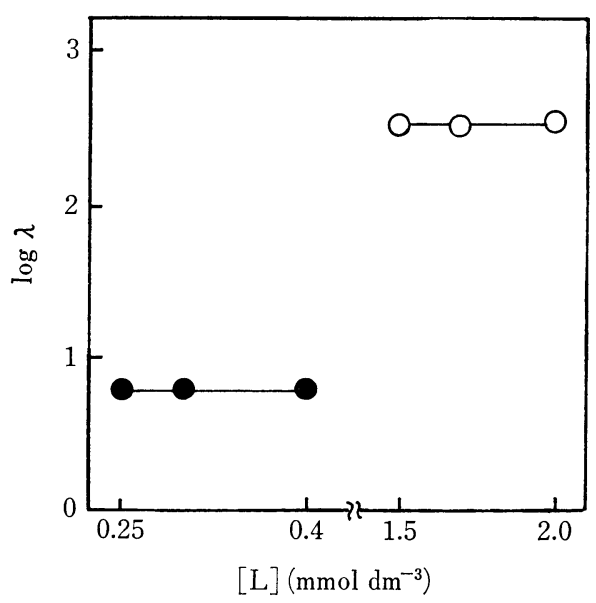

Fig. 3 Effect of 2,2'-bipyridyl concentration to corrected logarithmic distribution coefficients, $\lambda$.

$\bigcirc$ : calcite; $25^{\circ} \mathrm{C}, \quad$ : aragonite; $25^{\circ} \mathrm{C}$.

cium and cadmium at $i$-th sample solution pipetted from the calcium hydrogencarbonate solution. If the adsorption and occlusion is negligible, $\lambda_{0, j}>\lambda_{i, j}(i>0, \lambda<1)$ and $\lambda_{0, j}<\lambda_{i, j}$ $(i>0, \lambda>1)$ generally hold good when the crystal grows from a supersaturated solution. If $\lambda_{i, j}$ equals $\lambda_{i, k}$ within experimental errors, the effect of supersaturation is regarded as negligible, and is calculated as follows:

$$
\lambda=\sum_{j=i+1}^{N} \lambda_{i, j} /(N-i)
$$

$N$ is the total sample number in a run. The distribution coefficient was found independent of the mole fractions of $\mathrm{CdCO}_{3}$ in $\mathrm{CaCO}_{3}$ in the range between $5 \times 10^{-2}$ and $5 \times 10^{-4}$ indicating that the composition of dilute solid solution obeyed Henrry's law. Initial concentration of cadmium was fixed $5 \mu \mathrm{mol} \mathrm{dm}^{-3}$ in this experiment.

\subsection{Variation of distribution coefficient with temperature}

Ratner, Vaslow and Boyd ${ }^{15), 16)}$ gave a thermodynamic expression to Chlopin's distribution coefficient, $D$ as follows:

$$
D=\frac{K_{\mathrm{CaCO}_{3}}}{K_{\mathrm{CdCO}_{3}}} \cdot \frac{\gamma_{\mathrm{Cd}}}{\gamma_{\mathrm{Ca}}} \cdot \exp \left(\frac{-\Delta \mu}{R T}\right)
$$


Here $K_{\mathrm{CaCO}_{3}}$ and $K_{\mathrm{CdCO}_{3}}$ are the thermodynamic solubility product constants for $\mathrm{CaCO}_{3}$ and $\mathrm{CdCO}_{3}, \gamma_{\mathrm{Ca}}$ and $\gamma_{\mathrm{Cd}}$ mean molar activity coefficients for calcium and cadmium ions, and $\Delta \mu$ is excess free energy. The excess free energy is the partial molar energy involved in transferring one mole of cadmium ions from a large quantity of ideal solid solution to the real solid solution at the same mole fraction.

The second term, $\gamma_{\mathrm{Cd}} / \gamma_{\mathrm{Ca}}$, the ratio of the activity coefficients, can be calculated from Eq. (3) and Debye-Huckel's theory.

As ionic strength $I$ of the calcite formation experiment and the aragonite formation experiment were about 0.03 and 0.1 respectively, the theory is valid as:

$$
\ln \gamma_{i}=-\frac{A\left|Z^{+} Z^{-}\right| I^{1 / 2}}{1+B \cdot d \cdot I^{1 / 2}}
$$

Here $A$ and $B$ are constants and $d$ is a parameter of ionic radius. Distribution coefficients at various ionic strength were measured and the results are shown in Fig. 4. Distribution coefficients decreased with increase of ionic strength both calcite and aragonite. As linear relationship exists between $T^{-1}$ and $\ln$ $D$ from logarithmic expression of Eq. (10), $\log \lambda$ were plotted versus $T^{-1}$ in Fig. 5 , and good relationships were obtained.

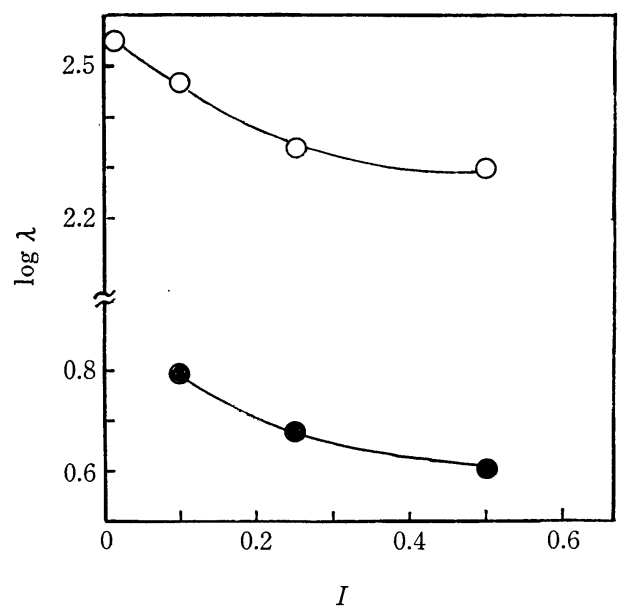

Fig. 4 Effect of ionic strength of solutions to the logarithmic distribution coefficients, $\lambda$.

$\mathrm{O}$ : calcite; $25^{\circ} \mathrm{C}$, $\mathrm{O}$ : aragonite; $25^{\circ} \mathrm{C}$.

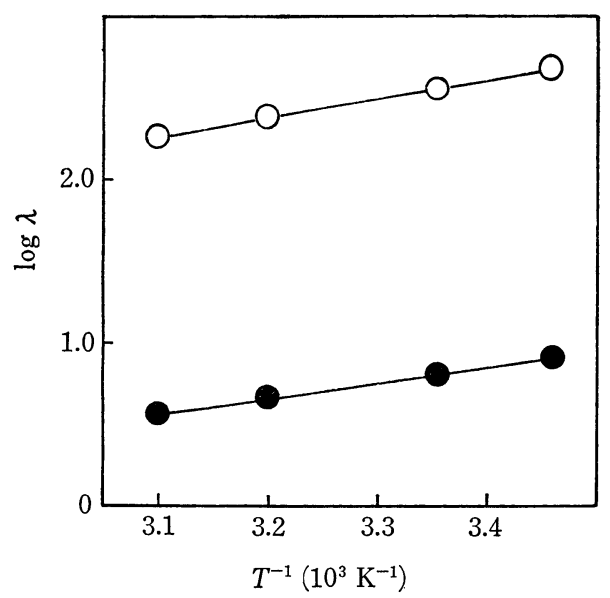

Fig. 5 Temperature dependence of distribution coefficients of cadmium with calcium carbonate.

O: $\mathrm{CdCO}_{3}-$ calcite, $\mathrm{O}: \mathrm{CdCO}_{3}-$ aragonite.

$\log \lambda=A T^{-1}+B$

The slope, $A_{\mathrm{cal}}=1.07 \times 10^{3}, A_{\mathrm{arg}}=8.56 \times 10^{2}$ and intercept, $B_{\mathrm{cal}}=-1.05, B_{\mathrm{arg}}=-2.07$ are obtained. Though the ratio of the solubility product constants is the most important factor to decide the distribution coefficient, reliable solubility product values of cadmium carbonate for the various temperatures have not been studied, the ratio value at 15,40 and $50{ }^{\circ} \mathrm{C}$ were regarded the same as the value at $25^{\circ} \mathrm{C}$. Solubility product constants of calcite, aragonite, cadmium carbonate ${ }^{16)}$ are $3.84 \times$ $10^{-9}, 5.30 \times 10^{-9}$, and $5.25 \times 10^{-12}$ at $25^{\circ} \mathrm{C}$.

\section{Conclusion}

Excess free energy values, distribution coefficient values and the ratios of activity coefficients of cadmium and calcium were given in Tables 1 and 2. The value $\gamma^{\mathrm{R}} \mathrm{rx}$, the activity of cadmium carbonate in a dilute solid solution with calcium carbonate, is 2.0 (Cd-calcite) and 150 (Cd-aragonite). As excess free energy value of cadmium with calcite, $1.76 \mathrm{~kJ} \mathrm{~mol}^{-1}$, is small compared with that of $\operatorname{zinc}(\mathrm{III})^{6), 7)}$, $5.86 \mathrm{~kJ} \mathrm{~mol}^{-1}$ (ionic radius $0.74 \mathrm{~nm}$ ), and that of manganese ${ }^{11)}, 5.40 \mathrm{~kJ} \mathrm{~mol}^{-1}$, (ionic radius $0.80 \mathrm{~nm}$ ), good solid solution may be formed in the calcium carbonate, for the ionic radius 
Table 1 Distribution coefficient and excess free energy carbonate-calcite system

\begin{tabular}{c|llll}
\hline & $15^{\circ} \mathrm{C}$ & $25^{\circ} \mathrm{C}$ & $40^{\circ} \mathrm{C}$ & $50^{\circ} \mathrm{C}$ \\
\hline$K_{\text {calcit }} / K_{\mathrm{CdCO}_{3}}$ & 731 & 731 & 731 & 731 \\
$\lambda$ & 472 & 350 & 236 & 186 \\
$\gamma_{\mathrm{Cd}} / \gamma_{\mathrm{Ca}}$ & 0.975 & 0.974 & 0.972 & 0.972 \\
$\Delta \mu\left(\mathrm{kJ} \mathrm{mol}{ }^{-1}\right)$ & 0.987 & 1.76 & 2.61 & 3.61 \\
\hline
\end{tabular}

Table 2 Distribution coefficient and excess free energy of cadmium carbonate aragonite system

\begin{tabular}{c|llll}
\hline & $15^{\circ} \mathrm{C}$ & $25^{\circ} \mathrm{C}$ & $40{ }^{\circ} \mathrm{C}$ & $50{ }^{\circ} \mathrm{C}$ \\
\hline$K_{\text {araqonite }} / K_{\mathrm{CdCO}_{3}}$ & 1010 & 1010 & 1010 & 1010 \\
$\lambda$ & 8.00 & 6.23 & 4.70 & 3.73 \\
$\gamma_{\mathrm{Cd}} / \gamma_{\mathrm{Ca}}$ & 0.941 & 0.940 & 0.936 & 0.935 \\
$\Delta \mu\left(\mathrm{kJ} \mathrm{mol}^{-1}\right)$ & 11.5 & 12.5 & 13.8 & 14.9 \\
\hline
\end{tabular}

of cadmium and calcium are similar size, $\mathrm{Cd}^{2+} ; 97 \mathrm{pm}$ and $\mathrm{Ca}^{2+} ; 99 \mathrm{pm}$, and the both crystal forms are the same, the hexagonal system. But the value of cadmium with aragonite, $12.5 \mathrm{~kJ} \mathrm{~mol}^{-1}$, is larger than that of calcite and smaller than that of manganese with aragonite, $19.7 \mathrm{~kJ} \mathrm{~mol}^{-1}$, because aragonite belongs to rhombic one and ionic radius of manganese is smaller than that of calcium.

The difference of excess free energy between calcite and aragonite, $10.7 \mathrm{~kJ} \mathrm{~mol}^{-1}$, is supposed to be originated from the transition energy of cadmium carbonate from hexagonal to rhombic system. The value is about 9.4fold greater than that of calcite-aragonite transition free energy at $25^{\circ} \mathrm{C}^{18)}$.

Excess molar enthalpy and molar entropy were calculated from the data of Tables 1 and 2 based on an assumption that the ratios of solubility products are equal to that of at $25^{\circ} \mathrm{C}$. The molar enthalpy and entropy of calcite are, $\Delta H_{\mathrm{cal}}=-19.8 \mathrm{~kJ} \mathrm{~mol}^{-1}$ and $\Delta S_{\mathrm{cal}}=$ $-71.9 \mathrm{~J} \mathrm{~K}^{-1} \mathrm{~mol}^{-1}$ and these of aragonite are $\Delta H_{\mathrm{arg}}=-16.1 \mathrm{~kJ} \mathrm{~mol}^{-1}$ and $\Delta S_{\mathrm{arg}}=-95.7 \mathrm{~J} \mathrm{~K}^{-1}$ $\mathrm{mol}^{-1}$, respectively.

\section{References}

1) Fujino, O., Kumagai, T., Sigematsu, T. and Matsui, M.: Bull. Inst. Chem. Res., Kyoto Univ., 54, 312 (1976)

2) Kumagai, T., Fujino, O., Matsui, M. and Sigematsu, T.: ibid., 54, 320 (1976)

3) Harrison, F.L. and Quinn, D.J.: Health Phys., 23, 509 (1972)

4) Holland, H.D., Holland, H.J. and Munoz, J.L.: Geochim. Cosmochim. Acta, 28, 1278 (1964)

5) Holland, H.D., Borcsik, M., Munoz, J. and Oxburgh, U.K.: ibid., 27, 957 (1963)

6) Tsusue, A. and Holland, H.D.: ibid., 30, 439 (1966)

7) Crocket, J.H. and Winchester, J.W.: ibid., 30, 1093 (1966)

8) Kitano, Y., Tokuyama, A. and Kanamori, N.: J. Earth Sci., Nagoya Univ., 16, 1 (1968)

9) Kitano, Y. and Oomori, T.: J. Oceanogr. Soc. Japan, 27, 34 (1971)

10) White, A.F.: Geochim. Cosmochim. Acta, 41, 613 (1977)

11) Kumagai, T. and Matsui, M.: Radioisotopes, 38, 3 (1989)

12) Anderegg, G.: Helv. Chim. Acta, 46, 2813 (1963)

13) Riehl, N., Sigmann, R. and Hidalgo, P.: Z. Phys. Chem., 25, 351 (1960)

14) Mcintire, W.L.: Geochim. Cosmochim. Acta, 27, 1209 (1963)

15) Ratner, A.P.: J. Chem. Phys., 1, 789 (1933)

16) Vaslow, F. and Boyd, G.E.: J. Amer. Chem. Soc., 74, 4691 (1952)

17) Latimer, E,M,: "Oxdation Potentials", 2 nd edition, p. 174, Prentice Hall, New York (1952)

18) Jamieson, J.C.: J. Chem. Phys., 21, 1385 (1953) 
要 旨

\title{
$15{ }^{\circ} \mathrm{C}$ から $50{ }^{\circ} \mathrm{C}$ の水溶液における炭酸カルシウムへの
} カドミウムの共沈殿

\author{
熊谷 哲, 松井正和*
}

姫路工業大学工学部基礎工学教室 671-22 兵庫県姫路市書写 2167

*京都大学化学研究所 611 京都府宇治市五ヶ庄

炭酸カルシウム（カルサイト，アラゴナイト）の沈殿と飽和した水溶液との間のカドミウムの分

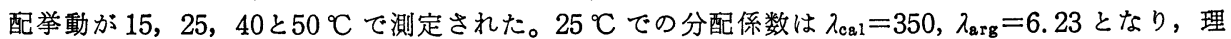
想固溶体と実際の固溶体との間の過剩自由エネルギーとして $\Delta \mu_{\mathrm{ca} 1}=1.76 \mathrm{~kJ} \mathrm{~mol}^{-1}, \Delta \mu_{\mathrm{arg}}=12.5 \mathrm{~kJ}$ $\mathrm{mol}^{-1}$ が得られた。この二つの過剩自由エネルギー值は結晶系の違いにより生じている。 